\title{
INVASION OF SCHRADER'S BROMEGRASS (BROMUS CATHARTICUS) AND EXPANSION OF THE CAIRO SUBURBAN LAND: ARE THEY IN COINCIDENCE?
}

\author{
PAVEL KovÁŘ \\ Department of Botany, Faculty of Science, Charles University in Prague, Benátská 2, \\ 12801 Praha 2, e-mail: kovar@natur.cuni.cz \\ Dedicated to Jana Osborn-Kosinová (Dept. Botany, Charles University in Prague), \\ a pioneer in Egyptian weed and invasion ecology, died in December 19, 2016
}

Received: $11^{\text {th }}$ January 2019, Accepted: $23^{\text {th }}$ January 2019

\begin{abstract}
Set of phytocoenological records obtained in nineties of the twentieth century from extensively farmed patches and/or grasslands dominated by invasive grass Bromus catharticus in suburban area of Cairo, Egypt, is related to running and perspective expansion of this vegetation formation in the "city ecotone" at the metropolitan boundry.

Keywords: Schrader's bromegrass, Bromus catharticus, invasion species, Cairo, Egypt, city ecotone, biodiversity, phytocoenological relevés, expansion, suburban zone, transition between urban and agricultural environment
\end{abstract}

\section{SUBURB AS A PERMEATION ZONE OF NEIGHBOURING AGRICULTURAL AND HOUSING AREAS}

There is some shift in using the term "ecotone" in the context of suburbia: from bioecological meaning of transition between two biological communities or environments (e.g., Orlóci et Orlóci, 1990; Hansen et di Castri, 1992; Kováŕ, 1992) to human-populated context of land where sociospatial boundaries are functionally, institutionally or materially redefined, in other words, where multiple layers of meaning in space coincide (Talen, 2015). Forman (2008) mentioned suburbs or peri-urban areas as components of neighbourhood ecology (in the meaning of movement patterns of biota or energy flows - a dynamic phenomenon on the zone of shortened gradient between urban and agricultural environment and/or abandoned land). In this sense, those belts represent a potential space for increased biodiversity, however, also for invading of adapted organisms (strong competitors or parazites) into suitable stages of vegetation succession (e. g., Kovár et al., 1997; El-Sheikh, 2003). The effect of urbanized core areas for climate warming within wider territories (Forman, 2014) is supporting factor for invasions of thermophilous species. One of the prominent plant species corresponding with named character is Schrader's bromegrass (Bromus catharticus) native to South America but found in other places, including Europe, Australia and North America, as an introduced taxon. 
Kovár.P.: Invasion of Schrader's bromegrass (Bromus catharticus) and expansion of the Cairo suburban land: Are they in coincidence?

\section{PLANT AND PHYTOCOENOLOGICAL MATERIAL}

Schrader's bromegrass (Bromus catharticus) was known from Egypt already many years ago (documented with herbaria sheets in Charles University Herbaria Collections in Prague PRC: 1950 - Khattab, 1952 - Boulos, 1952-1963 - El Hadidi, 1969 - Täckholm, 1971-1982 Kosinová, 1976 - Chrtek et Slavíková, 1980 - El Bakry, 1995 - Kovář), in publications mentioned among others by Jana Osborn-Kosinová during seventies of the past century (e.g., El Hadidi et Kosinová, 1971; Kosinová, 1972, 1974, 1975). This monumental, annual or biennial grass growing up to $1 \mathrm{~m}$ of height with diploid number of 42 has several English synonyms (e.g. common name rescuegrass refers to the ability of the species to provide forage after harsh droughts or extreme winters) and many Latin synonyms (Täckholm, 1974; Wiersema et León, 2013). Nomenclature of plants in this contribution is used according Täckholm (1974).

Twelve phytocoenological relevés $\left(16 \mathrm{~m}^{2}\right)$ recorded by the author of this short communication in April 5 - 9, 1995 at localities in Cairo El Mabosien City, Abo-Atata street, experimental plots - Faculty of Agriculture, Cairo University (underbrush of fig tree, banana plant or palm plantations) and in El-Zamalek island of the Nile (river bank grassland) show the community variability and species diversity. Records of presence and abundance in semiquantitative seven-grade scale were done in quadrats $4 \times 4 \mathrm{~m}$. The plant name is following by value of constancy (classes I - V with the growth by $20 \%$ degrees of the species frequency in the set of relevés) and extent of abundances in brackets - all this according Braun-Blanquet (1951). Species recorded: Bromus catharticus V (2 - 4), Sonchus oleraceus $\mathrm{V}(+-3)$, Conyza bonariensis IV $(\mathrm{r}-+)$, Melilotus indicus IV $(\mathrm{r}-2)$, Convolvulus arvensis IV $(\mathrm{r}-2)$, Digittaria sanguinalis IV ( $\mathrm{r}-2)$, Sorghum virgatum IV ( $\mathrm{r}-2)$, Ammi majus III ( $\mathrm{r}-1)$, Apium tenuifolium III (+ - 1), Emex spinosa III (+ - 3), Coronopus didymus III ( $\mathrm{r}-1)$, Sisymbrium irio III ( $\mathrm{r}-+)$, Setaria verticillata III ( $\mathrm{r}-1)$, Lolium temulentum II (1 - 3), Dichanthium annulatum II (r - 3), Euphorbia hyssopifolia II (+ - 1), Euphorbia indica II (r 1), Euphorbia peplus II ( $\mathrm{r}-1)$, Phalaris minor II ( $\mathrm{r}-1)$, Anagallis arvensis II (+ - 2), Bidens pilosa II ( $\mathrm{r}-+)$, Torilis arvensis II (+ - 2), Plantago major II $(\mathrm{r}-+)$, Plantago lagopus II $(\mathrm{r}-$ + ), Smilax aspera II (+ - 1), Stellaria pallida II (+), Poa annua I (+ - 2), Cynodon dactylon I $(+-1)$, Cyperus rotundus I $(\mathrm{r}-+)$, Chenopodium murale I $(\mathrm{r}-1)$, Eleusine indica I $(+-1)$, Rumex dentatus I (r - +), Lamium amplexicaule I (+), Amaranthus viride I (r), Amaranthus chlorostachys I (+), Xanthium strumarium I (1), Echinochloa colona I (+), Malva parviflora I (+), Cichorium endivia I (r), Oxalis corniculata I (r), Polypogon monspeliensis I (+), Senecio aegyptius I (r), Solanum nigrum I (r), Avena fatua I (r). Number of species in one relevé varies from 10 to 18 , total number of observed species is 44 . Physiognomic character of those stands is determined by their dominant Bromus catharticus (tall and dense grass stand). Wider area of the Nile Delta was floristically and phytosociologically sampled after 2006 (Mashaly 2009) incl. the stand with Bromus catharticus, and classified by TWINSPAN - a cluster with comparable floristic composition with our collection of relevés was established. More detailed insight into ecology of invasive plant species in the territory is done (Mashaly et al., 2011): dominance of Bromus catharticus correlates with slightly disturbed and subhalophile "cultural" habitats such as thermophilous grasslands near the river banks, channels and within orchards (Abd El-Ghani et al., 2011; Mashaly et al., 2016). The community could be classified within zurich-montpellier school of vegetation classification as subordered unit within phytocoenological alliance Melilotion indici with dominance of expansive grass Bromus catharticus (sensu Kosinová, 1975). 
Fig. 1: Grassland dominated by Bromus catharticus in the fig tree plantation at suburban zone of Cairo. Photo P. Kovář

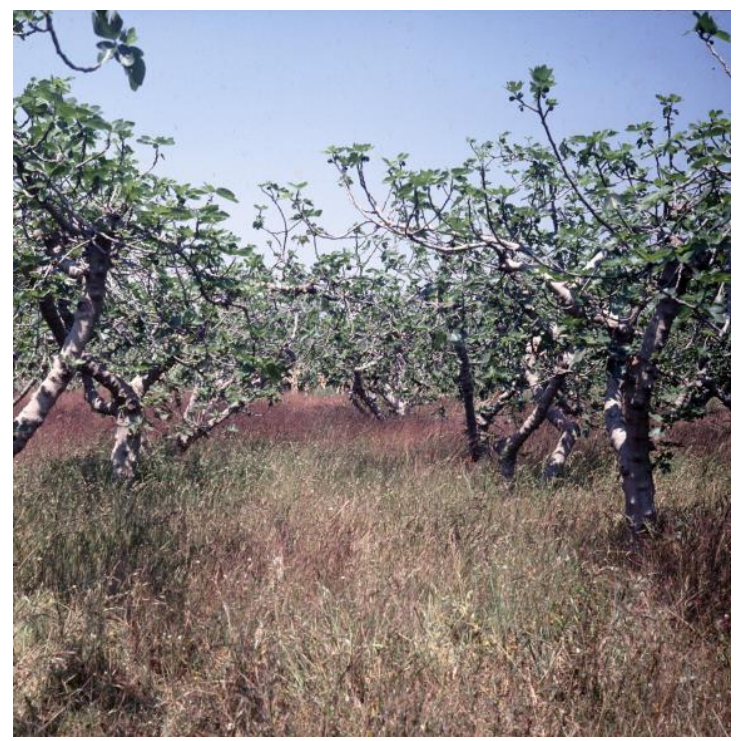

Fig. 2: Grassland margin with dominated Bromus catharticus in the banana plantation ("ecotonal" zone between agricultural and urban zone in Cairo). Photo P. Kovár

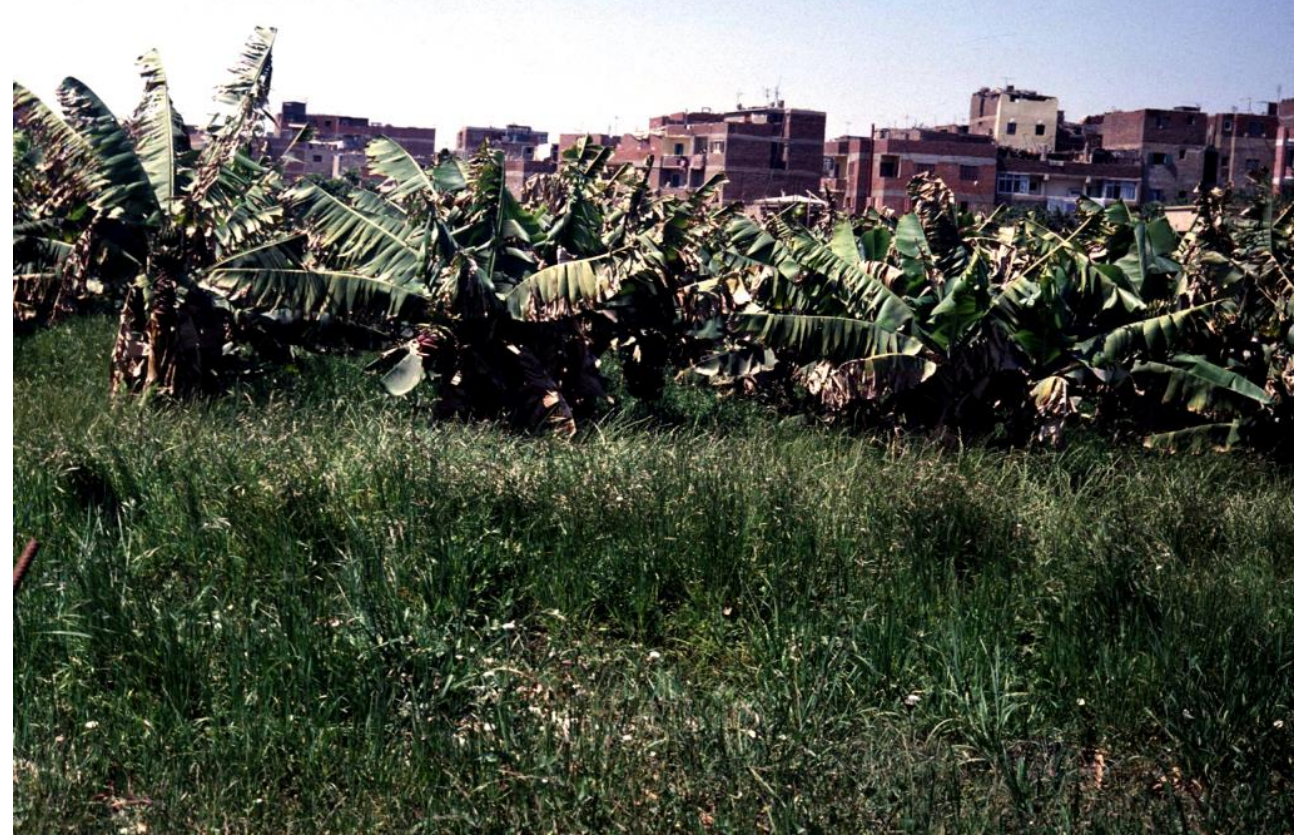


Kovár.P.: Invasion of Schrader's bromegrass (Bromus catharticus) and expansion of the Cairo suburban land: Are they in coincidence?

\section{EXPANSION OF LAND WITH NICHE OPEN FOR INVADERS IN THE CAIRO SUBURB}

Number of inhabitants in Cairo increased from nearly 6 millions in 1965 to approx. 10 millions in 1998 ((United Nations Population Division, World Urbanization Prospects, the 1999 revision) - density of human population in the Nile Delta belongs to the highest of the world (Dobrovolný et al., 2004). The built-up land enlarged since 1965 until recent times approx. three times in Cairo and this development is clearly documented by satellite images by the Earth Sciences and Image Analysis Laboratory (Johnson Space Center). It is likely that (sub)urbanization in future will continue to expand (Forman, 2016). We have been witnessed some degree of correlating "agro-suburban" landuse and occurrence of frequent patches occupied by alochtonous invaders - rescuegrass (Bromus catharticus) represents a conspicuous example. In fact, we can suppose that various factors such as human population development or climate change will influence this process of invasive landscape impacts facilitation. Monitoring of any invader expansion could be a challenge to detect indication of environmental threats.

\section{CONCLUSION}

Expansion of patches of land in Cairo occupied by grasslands with dominance of invasion species Bromus catharticus after development for tens of years is possible to correlate with multiple extension of suburban environment representing a kind of transition between urban and agriculture environment.

\section{REFERENCES}

Abd El-Ghani, M. M., Abou-El-Enain, M. M., Aboel, A., Hussein, E. A. (2011). Habitat heterogeneity and soil-vegetation relations in south of the Nile Delta, Egypt. Ecologia Mediterranea, 37(1), 53-68.

Braun-Blanquet J. (1951). Pflanzensoziologie. Ed. 2. Wien.

Dobrovolný, P., Herber, V., Hynek, A. (2004). Multimediální výuka předmětů krajinná ekologie a dálkový průzkum Země. Brno: Masarykova univerzita, katedra geografie. Online access, Retrieved June 18, 2018, from: http://www.sci.muni.cz/ dobro/zemsky_ povrch_urban.html

El Hadidi, M. N., Kosinová, J. (1971). Studies on the weed flora of cultivated land in Egypt. 1. Preliminary survey. Mitt. Bot. Staatssamml. München, 10, 354-367.

Forman, R. T. T. (2008). Urban Regions: Ecology and Planning Beyond the City. Cambridge University Press.

Forman, R. T. T. (2014). Urban Ecology. Science of Cities. Cambridge Univ. Press.

Forman, R. T. T., Wu, J. (2016). Where to put the next billion people? Nature, 537, 608-611. Hansen, A., di Castri, F. (1992). Landscape boundaries: Consequences for biotic diversity and ecologic al flows. Springer. Berlin, Heidelberg, New York.

Kosinová, J. (1972). On the weed flora and vegetation in Egypt. Egypt. Bot. Soc. Yearb., Cairo, 2, 1-6.

Kosinová, J. (1974). Studies on the weed flora of cultivated land in Egypt. Botanische Jahrbucher fur Systematik, 94, 449-458. 
Kosinová, J. (1975). Weed communities of winter crops in Egypt. Preslia, 47, 58-74.

Kovár̆, P. (1992). Ecotones in agricultural landscape. Ecology (CSFR), 11, 251-258.

Kovář, P., Hassan, E. A., Brabec, E. (1997). Is Vicia faba population affected by parasitism from Orobanche crenata more then by competition from non-parasitic weeds? Preslia, 69(2), 185-190.

Orlóci, L., Orlóci, M. (1990). Edge detection in vegetation: Jornada revisited. J. Veg. Sci., 1, 311-324.

Mashaly, I. A., El-Habashy, I. A., El-Halawany, E. F., Omar. G. (2009). Habitat and plant communities at the Nile Delta of Egypt II. Irrigation and drainage canal blank habitat. Pakistan Journal of Biological Sciences, 12(12), 885-895.

Mashaly, I. A., El-Halawany, E. F., Abd El-Gawad, A. M. (2011). Ecology of weeds and invasive plant species in newly reclaimed areas in Nile Delta, Egypt. Journal of Environmental Sciences, 40(1), 69-90.

Mashaly, I. A., Abd El-Gawad, A. M., Al-Barati, S. A. (2016). Floristic features of orchards in the newly reclaimed areas of Nile Delta, Egypt. Mansoura Journal of Biology, 41(1), 105-120.

Täckholm, V. (1974). Students' flora of Egypt. $2^{\text {nd }}$ Edition. Cairo University, Cairo.

Talen, E. (Ed) (2015). Retrofitting Sprawl: Addressing Seventy Years of Failed Urban Form. University of Georgia Press, Athens.

Wiersema, J. H., León B. (2013). World Economic Plants. A Standard Reference. $2^{\text {nd }}$ Edition. CRC Press, Boca Raton. 